\title{
Ecosystem changes associated with grazing intensity on the Punta Ninfas rangelands of Patagonia, Argentina
}

\author{
ANA M. BEESKOW, NESTOR O. ELISSALDE AND CESAR M. ROSTAGNO
}

Authors are range ecologist, CENPAT-CONICET, Puerto Madryn, Argentina; range ecologist, INTA, Trelew, Argentina; and soil scientist, CENPAT-CONICET, Puerto Madryn, Argentina.

\begin{abstract}
Changes in the vegetation and soil surface were assessed along a grazing intensity gradient on rangelands of the Punta Ninfas area in southern Argentina. Thirty-two transects were sampled in areas with different grazing intensity. Bray-Curtis polar ordination and simple correlation were used to display changes in community composition and measure association between different community attributes. The first axis expressed the changes in species composition along a gradient of grazing intensity. The extremes of the gradient were represented by shrub and grass steppes. Shrub steppes dominated in heavily grazed areas close to permanent water points, while grass steppes dominated in lightly grazed areas in the extremes of the paddocks. A significant negative relation $(x=-0.81, p<0.05)$ between grass and shrub cover suggested that grasses decreased as shrub increased. Flechilla (Stipa tenuis Phil.) and flechilla negra [Piptochaetium napostaense (Speg.) Hackel ap Stuckert.] were the main decreaser grasses while quilembai (Chuquiraga avellanedae Cav.) was the main shrub invading the grass steppes. Uneroded soil surface conditions decreased, and the size and frequency of crusted and desert pavement areas and mounds increased with shrub cover. Three states or stages of range degradation were identified along the gradient of grazing intensity. Grass steppe represented the most desirable state in term of livestock production and soil stability, while shrub steppe represented the most degraded and least productive state.
\end{abstract}

Key Words: range condition, erosion, shrub invasion, shrub/grass relationships, soil surface conditions.

Sheep grazing, one of the main economical activities of Patagonia, is based almost entirely on the natural vegetation. In most of the Patagonian rangelands, grazing appears to have modified the vegetation and accelerated soil degradation processes (Soriano et al. 1983, Beeskow et al. 1987, Ares et al. 1990). These changes are generally referred to as changes in range con-

The authors thank M.R. Marin and R. Mazzanti for computation assistance and M. Cornejo for help with the drawings. The research was supported by the Instituto Nacional de Tecnologia Agropecuaria, Trelew, and by the Consejo Nacional de Investigaciones Cientificas y Tecnicas, Puerto Madryn.

Manuscript accepted 5 Feb. 1995. dition, and are usually assessed from measurements of the quantity and composition of the vegetation (Stoddart et al. 1975). According to Wilson and Tupper (1982), range condition should be based primarily on soil stability as soil degradation is the most serious manifestation of a decline in range condition. Vegetation changes and soil degradation processes are closely related and may be site specific. Bosch and Kellner (1991) emphasized the importance of understanding the process of rangeland degradation before assessing the range condition of any area.

The development of a conceptual model of ecosystem changes through statistical procedures may contribute to an understanding of species responses to grazing, community changes that could be expected during degradation, and the recovery potential of land degraded to different degrees. Westoby et al. (1989) proposed that rangeland dynamics can be described by a set of discrete "states" of vegetation on a site and a set of "transitions" between states. They indicated that management criteria should be used in selecting and defining the states that occur in a given situation. Although the central problem of Patagonian rangelands is the advance of desertification due to overgrazing (Instituto Nacional de Tecnologia Agropecuaria, 1992), few studies have been undertaken to assess the deleterious changes in vegetation composition and soil degradation processes associated with grazing by domestic livestock. The objectives of this study were to define the extent of change along a gradient of grazing intensity, and to identify indicators of community deterioration and the different degradation stages in the Punta Ninfas area of Patagonia.

\section{Materials and Methods}

\section{Study Area}

The Punta Ninfas area (Beeskow et al. 1991) has an area of approximately $250 \mathrm{~km}^{2}$ (and is located in the north-east of the Chubut province in Patagonia, $70 \mathrm{~km}$ E of Puerto Madryn $\left(43^{\circ} 00^{\prime} \mathrm{S}, 64^{\circ} 30^{\prime} \mathrm{W}\right)$. It is an undulating plateau dissected by coastal valleys and interrupted by numerous depressions with playa lakes. Climate is arid and temperate. Mean annual precipitation from 1955-1992 was $254 \mathrm{~mm}$, and varied from $81 \mathrm{~mm}$ to a maximum of $519 \mathrm{~mm}$ in 1992, when sampling was conducted. Monthly and annual amounts are extremely variable. Most of the 
rainfall occurs during the cold season from April to September. Mean annual temperature is $12.5^{\circ} \mathrm{C}$. The mean annual wind velocity at $10 \mathrm{~m}$ above ground level is $4.6 \mathrm{~m} \mathrm{~s}^{-1}$ (Barros 1983).

Dominant soils are Xerollic Haplargids with some Xerollic Calciorthids and Typic Torriorthents (Soil Survey Staff, 1975). Haplargids are shallow with a loamy sand A horizon $5-15 \mathrm{~cm}$ thick, and a sandy loam B2t horizon $20-30 \mathrm{~cm}$ thick. A gravelly sand to sandy clay alluvium 50 to $80 \mathrm{~cm}$ thick forms the soil substratum. This deposit of Holocene age rests either on the "Patagonian Gravel" (Rodados Patagonicos) formation of PlioPleistocene age on the plateaus, or directly on the Tertiary sediments in the coastal plains and in the depressions.

Two main physiognomies characterize the vegetation of the Punta Ninfas area, herbaceous and shrub steppes. Perennial, coolseason bunch grasses and evergreen shrubs are the dominant bioforms of these communities; dwarf shrubs and ephemerals are secondary components. Foliar cover varies from $35 \%$ to $65 \%$, but may increase substantially in rainy periods when annuals contribute a high proportion of the total cover.

The area is located in the ecotone between the Patagonian and Monte phytogeographic provinces. Principal species representing the first province are the shrubs quilembai (Chuquiraga avellanedae Cav.), colapiche [Nassauvia fueguiana (Speg.) Cabrera], and neneo [Mulinum spinosum (Cav.) Pers.]. The cool-season grasses flechilla (Stipa tenuis Phil.) and flechilla negra [Piptochaetium napostaense (Speg. Hackel ap Stuckert.] are the main species of the Monte province.

Sheep grazing for wool production was introduced in the area at the begining of this century. Continuous grazing is practiced extensively in paddocks commonly exceeding 2,500 ha in size with a single permanent water point common to 3 or 4 paddocks. Mean stocking rate is 1 sheep $4 \mathrm{ha}^{-1}$.

\section{Sampling Procedure}

Sample sites were selected on aerial photographs of scale 1:60,000. Distances to permanent water points were taken into account in order to select sample sites with different grazing intensities. In October and November of 1992, 32 transects were located at these sites and sampled using the point quadrat method (Goodall 1952). Transects were $50 \mathrm{~m}$ long, and 100 points were recorded on each. A $1 \mathrm{~m}$-long pin was lowered at $50 \mathrm{~cm}$ intervals and foliar cover by species and soil surface condition (desert pavement, uneroded soil and mound) were recorded. Cover was calculated as the percentage of direct hits per transect.

Standing crop was determined at 6 of the sampling sites ( 2 per state or physiognomic classification, as described later). Herbaceous plants were clipped at a height of $0.5 \mathrm{~cm}$ in ten $0.5 \mathrm{~m}$ $\times 0.5 \mathrm{~m}$ quadrats per site, layed at fixed intervals along the transects. Samples were dried for 24 hours at $60^{\circ} \mathrm{C}$ and weighed.

\section{Data Analysis}

Ordination techniques allow major elements in the distribution patterns of different locations to be compared and related to independent environmental information (Friedel 1991). This approach does not assume a climax, but produces classes and orders of locations that define a degradation gradient according to known site factors, seasonal conditions, and land management. The polar ordination method (Cottam et al. 1973) with Jaccard's index of similarity as modified by Spatz (Mueller-Dombois and Ellenberg 1974) was used in this study. The sampling site with the lowest mean similarity with all other samples, and the sample with the lowest similarity value with that site were automatically selected as end points of the first axis along which all other samples were ordinated. Two sites located near the center of the first axis, but with low similarity, were selected as end points to define a second axis of ordination. Regression analyses were used to determine the relatinships of shrub cover to grass and mound cover.

\section{Results and Discussion}

\section{Sample Ordination and Degradation Gradient}

Sample ordinations along the first axis are given in Fig. 1. The $\mathrm{x}$-axis expressed the relative position of the samples along a gradient of community composition between samples 1 and 27 . Sample 1 was located adjacent to a water point representing heavily grazed areas, and sample 27 was located in the extreme of a paddock representing lightly grazed areas. This ordination fitted the preconceived utilization gradient, represented by a distance to permanent water points, which in turn was considered the main factor controlling range utilization. However, the fact that other temporary water points developed in the paddocks (i.e., in the playa lakes) could have altered the development of the pattern of utilization usually found in large paddocks with 1 water point. This, other factors controlling range utilization, and the variation in plant community due to environmental heterogeneity, could explain the distance of some stands to the $x$ axis. The ordination along the $y$ axis separated sites differing mainly in cover of pasto hilo (Poa lanuginosa Poiret). The high cover of pasto hilo, a rhizomatous cool-season grass that grows on loose sandy soils (Rostagno 1989), in samples close to one of the end points might indicate that the $y$-axis was related to the texture and thickness of the A horizon.

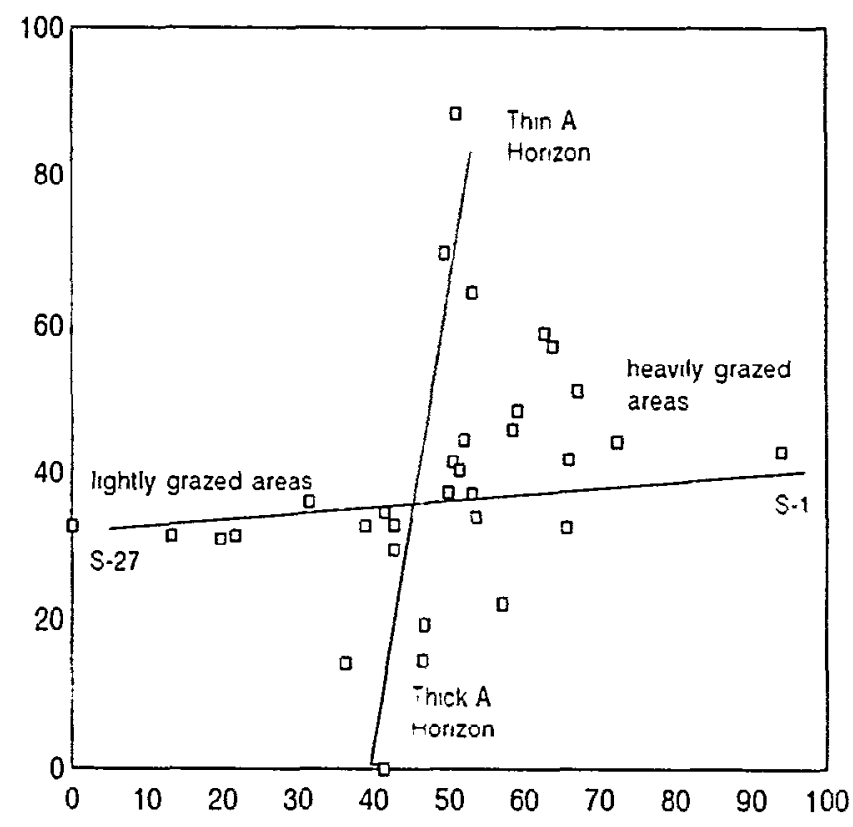

Fig. 1. Bray-Curtis polar ordination of 32 cover transects. The $x$ axis represents a grazing intensity gradient. S-1 is a heavily grazed area located adjacent to a permanent water point and S-27 is a lightly-grazed area in the opposite extreme of the paddock. The $y$ axis represents a gradient in the depth of the soil A horizon. 
Areas considered to be relatively unchanged or nondegraded were characterized by a grass steppe physiognomy and an homogeneous and stable soil surface condition. Changes in composition and abundance of forage species were observed along the main gradient, apparently reflecting vegetation response to grazing (Fig. 2). Under continuous grazing a decrease of palatable species and an increase in unpalatable species occurs. The 2 dominant species in the grass steppe, the cool-season bunchgrasses flechilla and flechilla negra, classified as highly palatable and palatable, respectively (Elissalde and Miravalle 1983), were con-

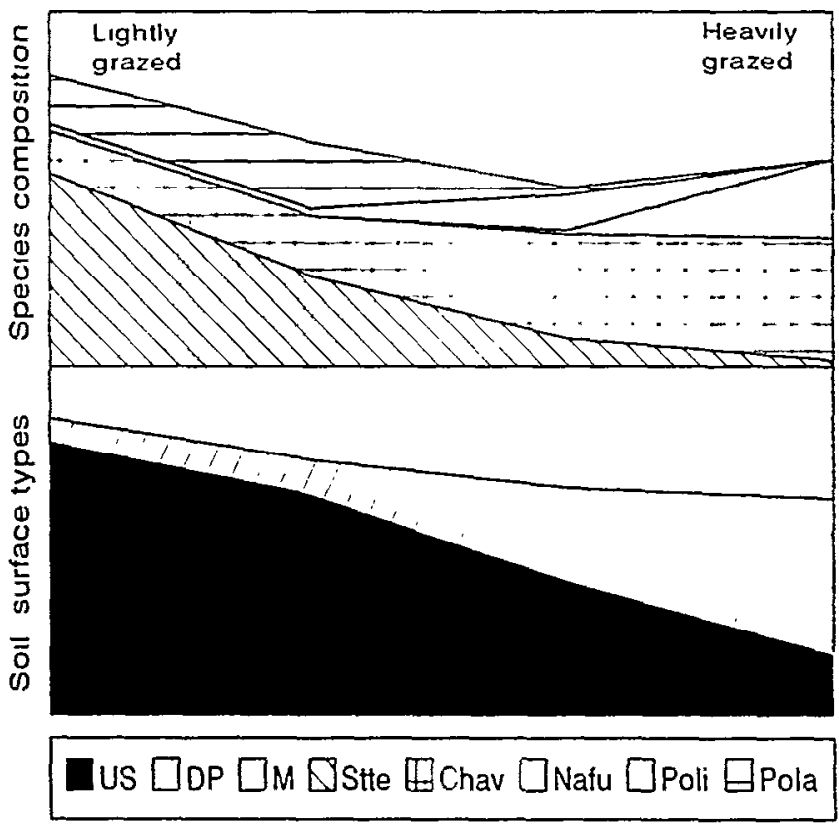

Fig. 2. Relative abundance of the principal species and soil surface types along a grazing intensity gradient. US: uneroded soil; DP: desert pavement; M. mounds; Stte: Stipa tenuis; Chav: Chuquiraga avellanedae; Nafu: Nassauvia fuegiana; Poli: Poa ligularis; Pola: $P$. languginosa.

sidered decreasers under light to moderate grazing. These species accounted for most of the forage production in nondegraded areas. Flechilla negra seemed to be either less tolerant to utilization or to changes in soil surface conditions as it decreased abruptly in even slightly grazed areas. At distances from water representative of moderately grazed areas, the perennial and highly palatable grasses coiron poa (Poa ligularis Nees ap. Steudel) and flechilla grande (Stipa longiglumis Philippi) were abundant and frequently found in the shrub interspaces. Near water, where grazing was considered to be severe, these species were only found where protected under shrubs.

As one moved toward water points, from lightly grazed to heavily grazed areas, the abundance of shrubs increased (Fig. 2). In the shrub-invaded areas, most of the A horizon had been translocated and accumulated beneath shrubs. Quilembai and colapiche, dominant shrubs in low areas along drainageways and around playa lakes with fine textured soils, invaded the adjacent grass steppe and became dominant in heavily grazed areas. Neneo, a shrub present on sandy soils, also invaded the grass steppe. The low palatability of these shrubs has likely been an important factor in the dominance in heavily grazed areas. The existance of mature plants of quilembai in the grass steppe promoted the formation of bare patches with desert pavements. This change appeared to have a positive effect on quilembai establishment since small individuals of quilembai were found in the degraded patches.

Palatable annual species, mostly introduced, such as verdin [Schismus barbatus (L.) Thell.], wild barleys (Hordeum sp.), and the winter annual forb stork's bill or alfilerillo [Erodium cicutarium (L.) L'Her.], significantly contributed to the total forage production in moderately degraded areas and were the main forage source in heavily degraded areas. Annuals were especially abundant in years with wet falls and/or winters, as occurred in the year of sampling.

\section{Community Indicators of Ecosystem Change}

The most important change recorded in the Punta Ninfas rangelands was the transformation of the grass stcppe into a shrub steppe. The cover of the perennial grasses, principally the dominant grass flechilla, decreased while that of shrubs increased. Quilembai was the most abundant shrub and the main indicator of range degradation. A highly negative relationship ( $r=-0.81$, $p<0.05$ ) between grass and shrub cover (Fig. 3) substantiated this observation. The transformation of former grassland into shrubland has been documented elsewhere (Buffington and Herbel 1965, Tueller and Blackburn 1974, Wickens and Whyte 1979, Herbel 1981).

Modifications of spatial plant distributions were associated with changes in botanical composition. As quilembai and other shrubs invade the grass steppe, the size of bare patches increases, leading to an acceleration of the erosion process and the formation of mounds (Fig. 4). However, the invading shrub neneo did not appear to promote the pattern of patches of desert pavement

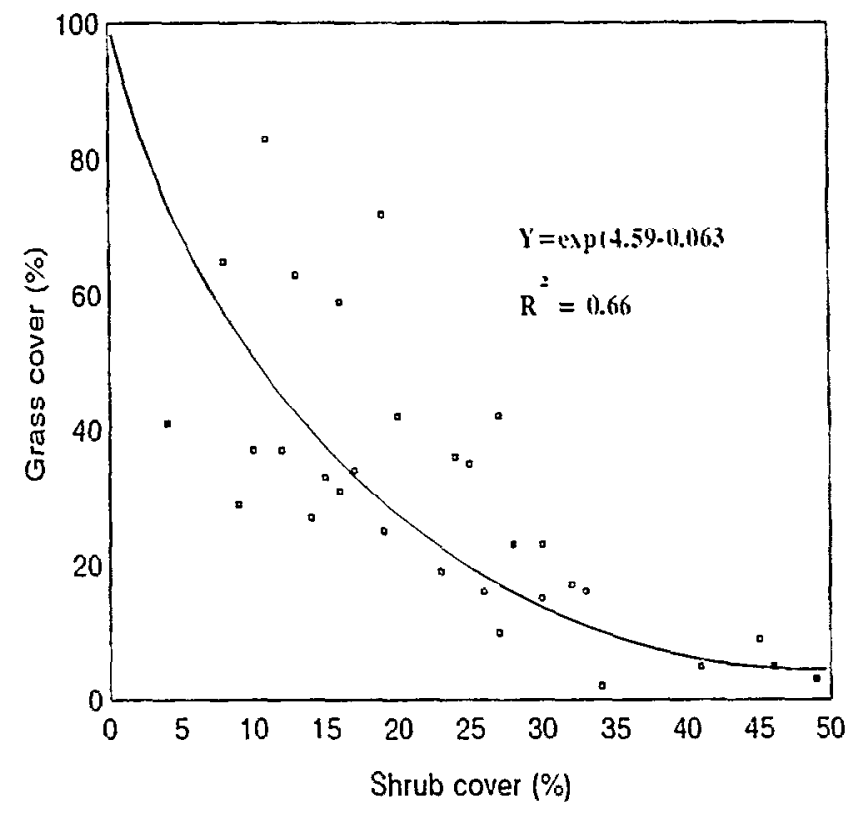

Fig. 3. Relationship between grass and shrub foliar cover in the Punta Ninfas rangelands of Patagonia. 
and mounds as did quilembai. The concept of determinant or "driver" species, originally used in the context of removing a species from an ecosystem (Walker 1992), could well be applied to quilembai because its invasion directly affects ecosystem processes such as erosion, soil infiltrability and nutrient cycling.

Accelerated erosion was followed by the formation of a desert pavement in the eroded areas and the formation of mounds beneath the shrubs. Thus, soil surface conditions were considered

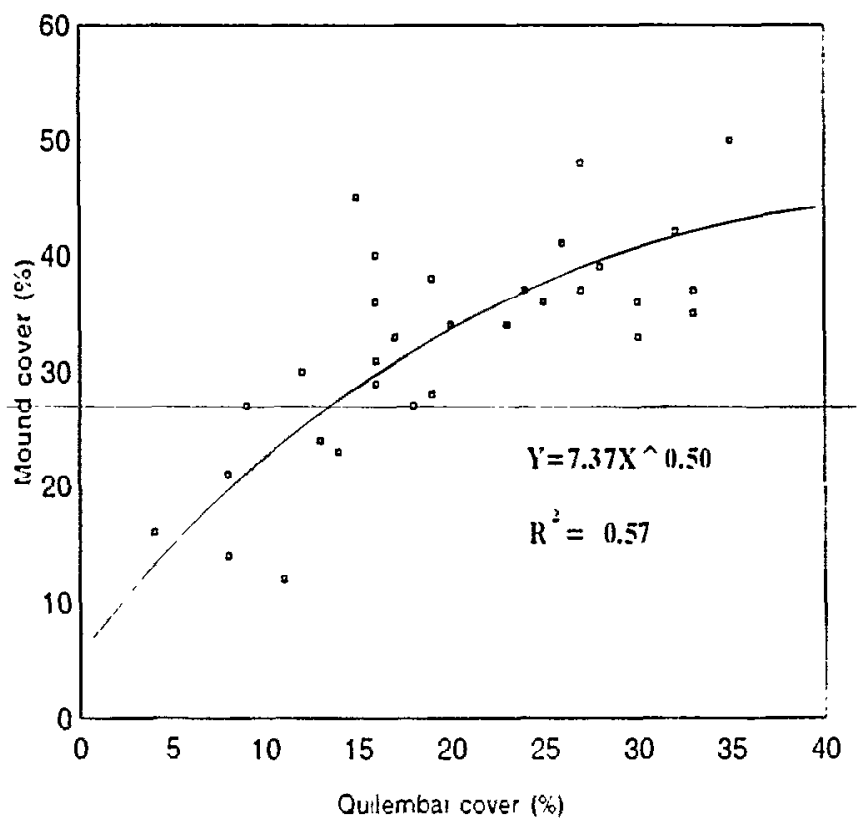

Fig. 4. Relationship between the percentage of soil surface covered by mounds and foliar cover of the shrub quilembai in the Punta Ninfas rangelands of Patagonia.

good indicators of soil degradation. These mounds seemed to be formed mainly by the accumulation of wind-blown material. In contrast, mounds associated with shrub clumps in the Puerto Madryn area $70 \mathrm{~km}$ west of the Punta Ninfa area were formed mainly by water erosion, with the mounds representing a relict of an ancient land surface (Rostagno and del Valle 1988). Mounds of eolic origin associated with shrubs, also termed coppice dunes (Melton 1940), were reported on soils with texture ranging from sand to sandy loam (Wood et al. 1978, Gile et al. 1981, Hennessy et al. 1986). Hodgkinson (1983) concluded that the presence of coppice dunes associated with Cutler Mormon-tea (Ephedra cutleri Peebles) on a loamy fine sand soil in northeastern Arizona indicated a decline in range condition. Soils of the Punta Ninfas area have a loamy sand $A$ horizon that appears to be very susceptible to wind erosion. As the A horizon was eroded from the shrub interspace, a bare and stable surface, characterized by a crust and a desert pavement, developed on the top of the sandy clay B2t horizon. Plant establishment on this surface appeared to be limited by excessive compaction.

Mounds and shrub interspace areas differ greatly in soil properties (Rostagno et al. 1991), with the mound soils representing better conditions in term of fertility and water balance. Schlesinger et al. (1990) proposed that the increase in heterogeneity of soil properties caused by shrub invasion could be a general measure of the changes in ccosystem function underlying various forms of desertification.

How much of the shrub encroachment and accelerated erosion in the Punta Ninfas area can be attributed to overgrazing is debatable. According to Wright and Bailey (1982), fire in combination with other factors would have been required to prevent shrub invasion in some North American desert grasslands. In those ecosystems, grazing would have reduced fine fuel for fires and allowed shrubs to invade (Chew and Chew 1965). In the Punta Ninfas rangelands, a role of fire is suggested by the observation that recent accidental fires on nearby areas have promoted the reestablishment of a grass steppe. Without fire, quilembai seems to replace perennial grasses, at least under moderate to heavy grazing.

\section{States and Transitions}

Cover data were readily categorized into 3 groups (Table 1), each representing a plant physiognomy that was easily recognized in the field. These physiognomic classifications may be viewed as the stable states of the state-and transition (boxes and arrows) concept of Westoby et al. (1989) (Fig. 5). Transitions between states can occur following certain climatic events and management practices. In the Punta Ninfas area, no references to climatic conditions conducive to a given state (i.e., shrub establishment) are available. However, heavy continuous grazing, by reducing perennial herbaceous vigor, appears to be a prerequisite for shrub establishment in the grass steppe (transition 1). The 2 extreme states, I and III, showed little internal variation in their species composition and structure. They were characterized by a grass steppe with little or no shrub cover, or a shrub or dwarfshrub steppe with little grass cover. Soil degradation in state I was neglegible although some mounds had developed. On the contrary, soil degradation in state III was generalized with maximum development of desert pavement and crust. Considerable variation in species composition occurs in the intermediate state. Grass/shrub steppes were more associated with soils with a thick sandy A horizon, with flechilla, pasto hilo, and desert needlegrass (Stipa speciosa Trin. and Rupr.) as dominant grasses, while shrub/grass steppes were more associated with soils with thin A horizons and coiron poa and flechilla grande as dominant grasses.

Many quilembai seedlings were found in bare areas between mature plants in areas assigned to states II and III. In contrast, few or no young shrubs were present in adjacent grass-dominated

Table 1. Mean foliar cover of principal plant species in each of the 3 states identified in the Punta Ninfas rangelands of Patagonia. Coefficients of variation appear in parentheses $(n=6)$. Data for States I, II, and III represent the left and right extremes and the center of the $\mathrm{x}$ axis of Fig. 1, respectively.

\begin{tabular}{|c|c|c|c|}
\hline Species & State I & State II & State III \\
\hline & \multicolumn{3}{|c|}{ (n) } \\
\hline Stipa tenuis & $46.2(35)$ & $12.2(48)$ & $3.8(67)$ \\
\hline S. speciosa & $3.0(69)$ & $2.2(95)$ & $1.3(84)$ \\
\hline Poa ligularis & $3.2(76)$ & $5.2(57)$ & $3.1(56)$ \\
\hline P. lanuginosa & $9.6(62)$ & $6.2(76)$ & $<1(95)$ \\
\hline Piptochaetium napostaense & $3.3(33)$ & $<1(75)$ & $<1(130)$ \\
\hline Chuguiraga avellanedae & $10.5(34)$ & $22.1(16)$ & $33.3(13)$ \\
\hline Mulinum spinosum & $<1(124)$ & $2.5(103)$ & $1.3(74)$ \\
\hline Nassauvia fueguiana & - & $<1(110)$ & $9.1(87)$ \\
\hline
\end{tabular}



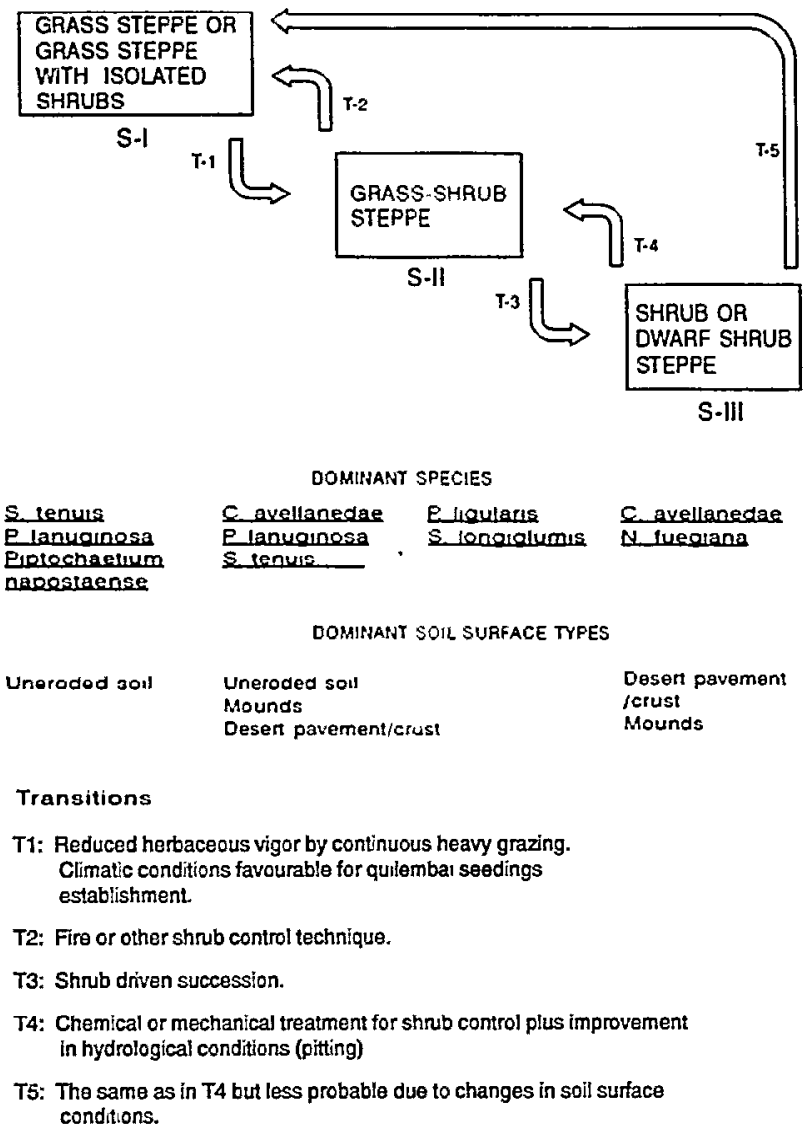

Fig. 5. State (S) and transition (T) diagram for the Punta Ninfas rangelands of Patagonia, including dominant plant species.

areas. The degradation of the soil surface could explain the alternating patches of grass steppe and patches of shrub steppe and be a principal factor in transition 3 .

Fire or other shrub control practices might be used to encourage transition 2, the change from the grass/shrub state (II) to grass steppe (I). However, the transition from shrub or dwarfshrub steppe (state III) to either state II (transition 4) or state I (transition 5) would be possible only by mechanical shrub control and improvement in hydrological conditions, such as pitting of the soil surface, because infiltration rates are very low (Rostagno 1989).

Availability of forage decreases dramatically from the grass steppe, through grass/shrub steppe, to shrub steppe (Fig. 6), mostly due to replacement by shrubs. The most common shrubs, quilembai, colapiche, and neneo, have very low forage value. In state III most of the herbaceous forage biomass was represented by annuals. In the succession model, condition represents the position of the vegetation along a continuum from heavilygrazed, early successional, poor condition, to ungrazed, climax, excellent condition. An important implication of this model for management is that range condition can be modified along this continuum by adjusting the stocking rate and providing time for the vegetation to equilibrate with it (Westoby et al. 1989). Although the different states (Fig. 5) might well represent seral stages with the grass steppe being the climaxic condition, it is

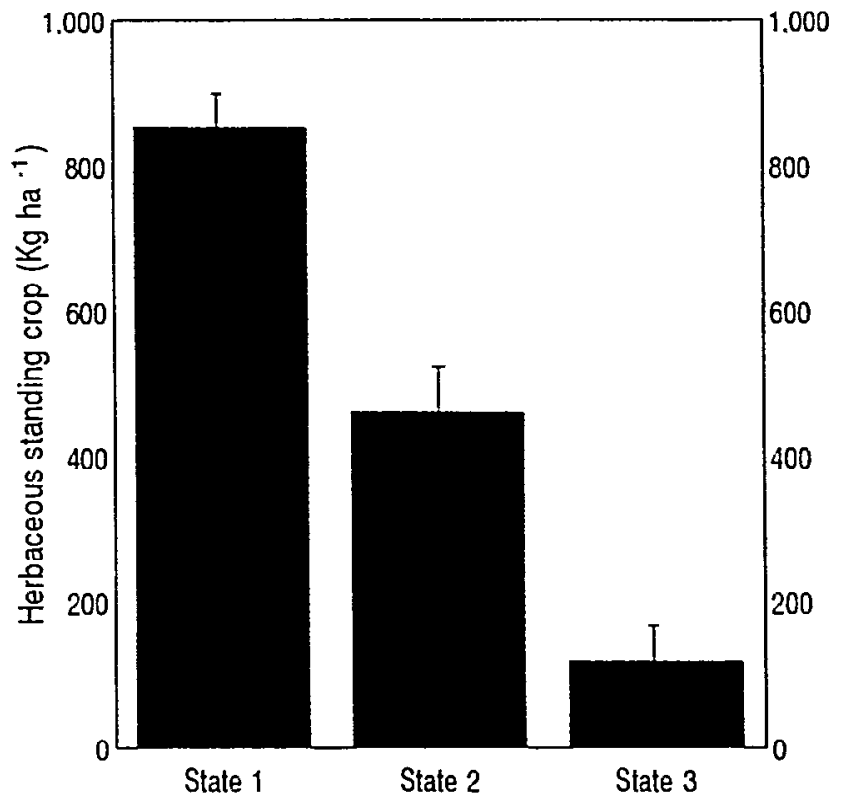

Fig. 6. Standing herbaceous biomass at 3 sampling points in each of the 3 defined states in the Punta Ninfas rangelands of Patagonia. Vertical bars are the standard error of the mean.

doubtful that recovery from shrub to grass steppe will occur following a decrease in the stocking rate or grazing exclusion, as similar examples indicate (Hennessy et al. 1983). Manipulations such as brush control, reseeding, and other reclamation practices seem necessary if rapid return to grass dominance is desired, as proposed by West et al. (1984) for a similar ecosystem that had not recovered after 13 years of grazing exclusion.

\section{Conclusions}

In the Punta Ninfas rangelands of Argentina, the main vegetation change associated with a gradient of utilization was the transformation of a grass steppe into a shrub steppe. The invasion of shrubs with low forage value into the grass steppe has decreased forage production. The invasion of shrubs, mainly quilembai, also affected soil stability by promoting the formation of crusts, desert pavement, and mounds. Shrub, desert pavement, and mound cover can be used as quantitative indicators of the extent of ecosystem degradation. Grass steppe represented the most desirable state in terms of forage production and soil stability, while shrub steppe represented the least productive state. The change from a shrub-dominated to grass-dominated community may be difficult to achieve through grazing management, and more drastic manipulations may be required if grass dominance is to be restored.

\section{Literature Cited}

Ares, J.O., A.M. Beeskow, M.B. Bertiller, C.M. Rostagno, M.P. Irisarri, J. Anchorena, O.E. Deffosse, and C.A. Merino. 1990. Structural and dynamic characteristics of the overgrazed grasslands of northern Patagonia, Argentina, p. 149-175. In: A Breymeyer (ed.), Managed Grasslands: Regional Studies. Elsevier, Amsterdam. 
Barros, V.R. 1983. Atlas del potencial eolico de la Patagonia. Contribucion no. 69, Centro Nacional Patagonico. Puerto Madryn, Chubut, Argentina.

Beeskow, A.M., H.F. del Valle, and C.M. Rostagno. 1987. Los sistemas fisiograficos de la region arida y semiarida de la Provincia del Chubut. Secretaria de Ciencia y Tecnol. Bariloche, Argentina.

Beeskow, A.M., N. Elissalde, and C.M. Rostagno. 1991. Delimitacion y caracterizacion de los sitios de pastoreo del sector noreste de la provincia de Chubut. X Reunion Nacional para el Estudio de las Regiones Aridas y Semiaridas. Bahia Blanca, Argentina.

Bosch, O.J.H., and K. Kellner. 1991. The use of degradation gradient for the ecological interpretation of condition assessments in the western grassland biome of southern Africa. J. Arid Environ. 21:21-29.

Buffington, L.C., and C.H. Herbel. 1965. Vegetation changes on a semidesert grassland range from 1858 to 1963. Ecol. Monog. 35:139-164.

Cottam, G., F.G. Goff, and R.H. Whittaker. 1973. Wisconsin comparative ordination, p. 195-221. In: R.H. Whitaker (ed.), Ordination and classification of communities. Junk, The Hague.

Chew, R.M., and A.E. Chew. 1965. The primary productivity of a desert-shrub (Larrea tridentata) community. Ecol. Monog. 35:355-375.

Elissalde, N.O., and H.R. Miravalle. 1983. Evaluacion de los campos de pastoreo de Peninsula Valdes. Contribucion no. 70, Central Nacional Patagonico, Puerto Madryn, Chubut, Argentina.

Friedel, M.H. 1991. Range condition assessment and the concept of thresholds: A viewpoint. J. Range Manage. 44:422-426.

Gile, L.H., J.W. Hawley, and R.B. Grossman. 1981. Soils and geomorphology in the basin and range area of southern New Mexico. Guidebook to the Desert Project. New Mexico Bureau of Mineral Resources. Memoir 39.

Goodall, D.W. 1952. Some considerations in the use of point quadrats for the analysis of vegetation. Aust. J. Sci. Res., Series B:1-41.

Hennessey, J.T., R.P. Gibbens, J.M. Tromble, and M. Cardenas. 1983. Vegetation changes from 1935 to 1980 in mesquite dunelands and former grassiands of southern New Mexico. J. Range Manage. $36: 370-374$

Hennessey, J.T., B. Kies, R.P. Gibbens, and J.M. Tromble. 1986. Soil sorting by forty-five years of wind erosion on a southern New Mexico range. Soil Sci. Soc. Amer. J. 50:391-394.

Herbel, C.H. 1981. Manipulative range improvements. Principles and practices, p. 557-579. In: Manassah, J.T., and E.J. Briskey (eds.), Advances in food-producing systems for arid and semiarid lands. Academic Press, N.Y.

Hodgkinson, H.S. 1983. Relationship between Cutler Mormon Tea [Ephedra cutleri] and coppice dunes in determining range trend in northeastern Arizona. J. Range Manage. 36:375-377.

Instituto Nacional le Tecnologia Agropecuaria. 1992. Proyecto de prevencion y control de la desertificacion en la Patagonia. Secret. de. Agr. Ganaderia y Pesca (SAGYP), INTA. Buenos Aires.

Melton, F.A. 1940. A tentative classification of sand dunes: its application to dune history in the southern High Plains. J. Geology 48:113-174.

Mueller-Dumbois, D., and H. Ellenberg. 1974. Aims and methods of vegetation ecology. John Wiley and Sons, N.Y.

Rostagno, C.M. 1989. Infiltration and sediment production as affected by soil surface conditions in a shrubland of Patagonia, Argentina. J. Range Manage. 42:382-385.

Rostagno, C.M., and H.F. del Valle. 1988. Mounds associated with shrubs in aridic soils of northeastern Patagonia: characteristics and probable genesis. Catena 15:347-359.

Rostagno, C.M., H.F. del Valle, and L. Videla. 1991. The influence of shrubs on some chemical and physical properties of an aridic soil in north-eastern Patagonia, Argentina. J. Arid Environ. 20:179-188.

Schlesinger, W.H., S.F. Reynolds, O.L. Cunningham, L.F. Huenneke, W.M. Jarrel, R.A. Virginia, and W.G. Whitford. 1990. Biological feedbacks in global desertification. Sci. 247:1043-1048.

Soil Survey Staff. 1975. Soil taxonomy: a basic system of soil classification for making and interpreting soil surveys. USDA Agr. Handb. 436.

Soriano, A., W. Volkheimer, H. Walter, E.O. Box, A.A. Marcolin, J.A. Valerini, C.P. Movia, R.J. Leon, J.M. Gallardo, M. Rumboll,
M. Canevari, P. Canevari, and W.G. Vasina. 1983. Deserts and semi-deserts of Patagonia, p. 423-460. In: N.E. West (ed.), Ecosystems of the world. Temperate deserts and semi-deserts. Elsevier, Amsterdam.

Stoddart, L.A., A.D. Smith, and T.W. Box. 1975. Range management. Third ed. McGraw-Hill, New York, N.Y.

Tueller, P.T., and W.H. Blackburn. 1974. Condition and trend of the big sagebrush/needleandthread habitat type in Nevada. J. Range Manage. 27:36-40.

Walker, B.H. 1992. Biological and ecological redundancy. Conserv. Biol. 6:18-23.

West, N.E., F.D. Provenza, P.S. Johnson, and M.K. Owens. 1984. Vegetation changes after 13 years of livestock grazing on sagebrush semidesert in west central Utah. J. Range Manage. 37:262-264.

Westoby, M., B. Walker, and I. Noy-Meyer. 1989. Opportunistic management for rangelands not at equilibrium. J. Range Manage. 42:266-274.

Wickens, G.E., and L.P. White. 1979. Land use in the southern margins of the Sahara, p. 205-242. In: B.H. Walker (ed.), Management of Semiarid Ecosystems. Elsevier, Amsterdam.

Wilson, A.D., and G.J. Tupper. 1982. Concepts and factors applicable to the measurements of range condition. J. Range Manage. 35:684-689.

Wood, M.K., W.H. Blackburn, R.E. Eckert, and F.F. Peterson. 1978. Interrelations of the physical propertics of coppices dunes in detcrmining range trend in northeastern Arizona. J. Range Manage. 31:189-192.

Wright, H.A., and A.W. Bailey. 1982. Fire Ecology. John Wiley and Sons, N.Y. 